\title{
ДОСЛІДЖЕННЯ ЕНЗИМНОЇ ЛАНКИ АНТИОКСИДАНТНОЇ СИСТЕМИ В ЩУРІВ ЗА УМОВИ ДІЇ ТЮТЮНОВОГО ДИМУ НА ТЛІ ЗАСТОСУВАННЯ НАТРІЙ ГЛУТАМАТУ В СТАТЕВОМУ І ВІКОВОМУ АСПЕКТАХ
}

Вступ. Значна розповсюдженість тютюнокуріння - глобальна проблема людства, на вирішення якої спрямовані зусилля багатьох учених і фрахівців. Водночас відмітною особливістю сучасних харчових технологій є використання харчових добавок. До найпоширеніших харчових добавок як в Україні, так і в Європі належить натрій глутамат (E621), який не завжди безпечний для здоров'я людини.

Мета дослідження - вивчити стан ензимної ланки антиоксидантної системи в щурів за умови діі тютюнового диму на тлі застосування натрій глутамату в статевому і віковому аспектах.

Методи дослідження. Досліди проведено на 96 білих нелінійних статевозрілих і статевонезрілих щурах обох статей. Кожну групу тварин було поділено на 4 підгрупи: 1-ша - контроль; 2-га - щури, яким моделювали "пасивне тютюнокуріння"; 3-тя - щури, яким вводили натрій глутамат; 4-та - щури, яким моделювали “пасивне тютюнокуріння" на тлі введення натрій глутамату.

Результати й обговорення. Надмірне утворення продуктів вільнорадикального окиснення за умови ізольованої дії тютюнового диму викликало виснаження антиоксидантного потенціалу крові та тканин легень, що проявлялося достовірним зменшенням супероксиддисмутазної активності в гемолізатах еритроцитів на 28,8 \% відносно контрольної групи, а в супернатанті гомогенату легень - на 53,1 \% ( $<<0,001)$ відповідно. "Пасивне тютюнокуріння" на тлі застосування натрій глутамату супроводжувалося більшим ії зниженням (на 41,0 \%, p<0,001) відносно контрольної групи, що на 17,1 \% (p<0,02) менше від даного показника при ізольованій дії тютюнового диму в гемолізатах еритроцитів та на 58,7 \% - у супернатанті гомогенату легень, що на 12,0% (p<0,02) нижче від цього показника за умови ізольованої дії тютюнового диму. Однонаправлені зміни спостерігали і щодо каталазної активності.

Висновки. За умови дії тютюнового диму спостерігають виснаження антиоксидантного потенціалу (зниження супероксиддисмутазної і каталазної активності) крові та тканин легень, більш виражене при “пасивному тютюнокурінні" на тлі застосування натрій глутамату. В статевому аспекті показники антиоксидантного захисту за умови “пасивного тютюнокуріння" на тлі застосування натрій глутамату більш виражено знижуються в самок, а при віковому зіставленні змін активності даних ензимів встановлено їх інтенсивніше зменшення у статевонезрілих щурів.

КЛЮчОВІ СЛОВА: тютюновий дим; натрій глутамат; антиоксидантна система.

ВСТУП. Вживання тютюну є однією з основних причин захворювань, яким можна запобігти, і передчасної смерті в усьому світі. На глобальному рівні від пов'язаних 3 тютюном хвороб щорічно помирає близько 7 мільйонів осіб (більше 19000 щодня). Понад 6 мільйонів таких смертей є результатом прямого впливу тютюнового диму, а близько 890000 випадків наслідком впливу пасивного тютюнокуріння. Якщо сучасні тенденції поширеності куріння збережуться, то можна очікувати, що до 2030 р. смертність від пов'язаних 3 тютюном хвороб збільшиться до 8 мільйонів осіб на рік [1-4].

(с) А. В. Руцька, 2018.
За результатами дослідження GATS в Україні [5], у 2017 р. 23,0 \% (8,2 мільйона) дорослого населення України повідомили про вживання тютюну (використання тютюнових виробів щоденно або рідше ніж щодня) в будь-якій фрормі (40,1 \% чоловіків та 8,9 \% жінок). У цілому 22,8 \% дорослого населення на даний момент курять тютюнові вироби (39,7 \% серед чоловіків та 8,8 \% серед жінок). Загалом 20,1 \% (7,2 мільйона) дорослого населення курять щодня (35,9 \% ceред чоловіків та 7,0 \% серед жінок). Серед щоденних курців тютюну 69,2 \% повідомили про те, що викурюють першу сигарету протягом 30 хв після пробудження. Середній вік початку куріння 
для осіб віком 18-34 роки, які будь-коли курили щодня, становить 16,8 року, а 60,4 \% курців почали курити до досягнення 18-річного віку.

Водночас відмітною особливістю сучасних харчових технологій $є$ використання харчових добавок, які виконують технологічні фрункції, поліпшують органолептичні властивості харчових продуктів і не завжди є безпечними для здоров'я людини [6]. Однією з найпоширеніших харчових добавок як в Україні, так і в Європі $€$ натрій глутамат [7]. Реальна загроза одночасного надходження в організм тютюнового диму та натрій глутамату надає вивченню їх поєднаної дії особливої актуальності.

Важлива роль у реалізації токсичної дії ксенобіотиків належить оксидативному стресу, який пов'язаний з порушенням збалансованості антиоксидантної та прооксидантної систем. Саме наявність та адекватне фрункціонування системи антиоксидантного захисту дозволяє клітинам підтримувати внутрішньоклітинну концентрацію оксидантів на безпечному рівні, запобігаючи ушкоджувальному впливу високореакційноздатних активних форм кисню (АФК) на будь-які макромолекули (нуклеїнові кислоти, ліпіди, білки) [8]. За дії АФК у клітинах відбувається експресія редоксчутливих генів, більшість з яких необхідна для захисту клітин від токсичних есректів, зокрема генів каталази і супероксиддисмутази.

Мета дослідження - вивчити стан ензимної ланки антиоксидантної системи в щурів за умови дії тютюнового диму на тлі застосування натрій глутамату в статевому і віковому аспектах.

МЕТОДИ ДОСЛІДЖЕННЯ. Досліди проведено на 32 безпородних статевозрілих білих щурах-самцях 3 початковою масою 180-200 г, 32 безпородних статевозрілих білих щурах-самках 3 початковою масою 180-200 г та 32 безпородних статевонезрілих білих щурах-самцях 3 початковою масою 60-80 г.

Кожну групу тварин було поділено на 4 підгрупи: 1-ша - контроль ( $\mathrm{n=8}$ ); 2-га - щури, яким моделювали "пасивне тютюнокуріння" $(\mathrm{n}=8)$; 3-тя - щури, яким вводили натрій глутамат $(\mathrm{n}=8)$; 4-та - щури, яким моделювали "пасивне тютюнокуріння" на тлі введення натрій глутамату $(\mathrm{n}=8)$.

Моделювали "пасивне тютюнокуріння" шляхом поміщення щурів у спеціально сконструйовану камеру з оргскла, в якій розподіляли тютюновий дим. Розрахунок еквівалентної дози нікотину і часу експозиції тварин тютюновим димом проводили на підставі апробованої моделі А. С. Соломіної [9] і розрахунків Л. В. Лізурчик та О. В. Шейди [10]. Задимлювали камеру шляхом спалювання двох цигарок "Прима срібна (червона)" (смоли - 10 мг/сиг., нікотин - 0,8 мг/сиг.).
Піддослідні тварини проходили процедуру “пасивного куріння" 2 рази на добу по 30 хв. Тривалість експерименту становила 30 днів.

Тваринам 2-ї дослідної групи протягом 30 днів внутрішньошлунково вводили натрій глутамат у дозі $30 \mathrm{мг/кг,} \mathrm{розчинений} \mathrm{у} \mathrm{0,5} \mathrm{мл}$ дистильованої води кімнатної температури [11].

Щурам 3-ї дослідної групи моделювали “пасивне тютюнокуріння" і вводили натрій глутамат. Усі маніпуляції з експериментальними тваринами виконували з дотриманням правил відповідно до Європейської конвенції про захист хребетних тварин, що використовуються для дослідних та інших наукових цілей [12].

Супероксиддисмутазну активність (СОД, 1.1.15.1.) визначали за методом [13], принцип якого полягає у відновленні нітротетразолію супероксидними радикалами, та виражали в умовних одиницях на 1 мг протеїну. Каталазну активність (каталаза, 1.11.1.6) визначали спектрофротометричним методом [14] та виражали у ммоль $\mathrm{H}_{2} \mathrm{O}_{2}$ /хв на 1 мг протеїну, використовуючи коефіцієнт молярного поглинання, який дорівнює $22,2 \cdot 10^{3} \mathrm{MM}^{-1} \cdot \mathrm{CM}^{-1}$.

Статистичну обробку цисррових даних здійснювали за допомогою програмного забезпечення Excel ("Microsoft", США) і STATISTICA 6.0 ("Statsoft", США) з використанням параметричних і непараметричних методів оцінки одержаних даних. Для всіх показників розраховували значення середньої арифрметичної вибірки (М), її дисперсії і помилки середньої (m). Достовірність різниці значень між незалежними кількісними величинами визначали за допомогою критерію Стьюдента або Манна-Уїтні. Зміни вважали статистично достовірними при $р<0,05$.

РЕЗУЛЬТАТИ Й ОБГОВОРЕННЯ. ЕрИТрОЦИти, тісно контактуючи з усіма тканинами і вступаючи з ними в морфоорункціональні взаємини, власною якісною та кількісною перебудовою відображають фізіологічні й патологічні зміни, які відбуваються в організмі. Полісункціональна роль еритроцитів у механізмах адаптації і компенсації при гіпоксії, газотранспортних процесах та виконанні інших життєво важливих фуннкцій пояснює високу інформативність результатів вивчення функціональних змін у даних клітинах $[15,16]$. Це спонукало нас дослідити показники ензимної ланки антиоксидантного захисту, крім тканини легень, у супернатанті гемолізатів еритроцитів. Результати визначення супероксиддисмутазної та каталазної активності у гемолізатах еритроцитів контрольних і піддослідних тварин наведено в таблиці 1.

Головною і першорядною перешкодою на шляху утворення АФК є супероксиддисмутаза. 
Таблиця 1 - Вплив “пасивного тютюнокуріння" і натрій глутамату на показники антиоксидантного захисту в гемолізатах еритроцитів щурів $(\mathrm{M} \pm \mathrm{m}, \mathrm{n}=8)$

\begin{tabular}{|c|c|c|c|c|}
\hline \multirow[b]{2}{*}{ Показник } & \multicolumn{4}{|c|}{ П Підгрупа тварин } \\
\hline & контроль & $\begin{array}{c}\text { "пасивне } \\
\text { тютюнокуріння" }\end{array}$ & $\begin{array}{c}\text { натрій } \\
\text { глутамат }\end{array}$ & $\begin{array}{c}\text { “пасивне } \\
\text { тютюнокуріння"+натрій } \\
\text { глутамат }\end{array}$ \\
\hline \multicolumn{5}{|c|}{ Статевозрілі щури-самці } \\
\hline $\begin{array}{l}\text { СОД, } \\
\text { ум. од./мг білка }\end{array}$ & $32,69 \pm 0,46$ & $\begin{array}{c}23,28 \pm 1,04 \\
p_{1}<0,001\end{array}$ & $\begin{array}{c}26,90 \pm 0,67 \\
p_{1}<0,001\end{array}$ & $\begin{array}{c}19,29 \pm 0,83 \\
p_{1}<0,001 \\
p_{2}<0,02\end{array}$ \\
\hline $\begin{array}{l}\text { Каталаза, } \\
\text { ммоль } \mathrm{H}_{2} \mathrm{O}_{2} / \text { хв·мг білка }\end{array}$ & $18,78 \pm 0,68$ & $\begin{array}{c}15,70 \pm 0,63 \\
p_{1}<0,02\end{array}$ & $\begin{array}{c}12,53 \pm 0,71 \\
p_{1}<0,001\end{array}$ & $\begin{array}{c}10,91 \pm 0,41 \\
\mathrm{p}_{1}<0,001 \\
\mathrm{p}_{2}<0,001\end{array}$ \\
\hline \multicolumn{5}{|c|}{ Статевозрілі щури-самки } \\
\hline $\begin{array}{l}\text { СОД, } \\
\text { ум. од./мг білка }\end{array}$ & $38,43 \pm 0,85$ & $\begin{array}{c}20,79 \pm 0,94 \\
p_{1}<0,001\end{array}$ & $\begin{array}{c}35,00 \pm 0,90 \\
p_{1}<0,05\end{array}$ & $\begin{array}{c}16,70 \pm 0,72 \\
p_{1}<0,001 \\
p_{2}<0,01\end{array}$ \\
\hline $\begin{array}{l}\text { Каталаза, } \\
\text { ммоль } \mathrm{H}_{2} \mathrm{O}_{2} / \text { хв·мг білка }\end{array}$ & $20,25 \pm 1,00$ & $\begin{array}{c}14,59 \pm 0,73 \\
p_{1}<0,002\end{array}$ & $\begin{array}{c}12,65 \pm 0,48 \\
p_{1}<0,001\end{array}$ & $\begin{array}{c}8,72 \pm 0,39 \\
p_{1}<0,001 \\
p_{2}<0,001\end{array}$ \\
\hline \multicolumn{5}{|c|}{ Статевонезрілі щури-самці } \\
\hline $\begin{array}{l}\text { СОД, } \\
\text { ум. од./мг білка }\end{array}$ & $30,28 \pm 0,93$ & $\begin{array}{c}14,98 \pm 0,73 \\
p_{1}<0,001\end{array}$ & $\begin{array}{c}23,19 \pm 0,89 \\
p_{1}<0,001\end{array}$ & $\begin{array}{c}10,05 \pm 0,30 \\
p_{1}<0,001 \\
p_{2}<0,001\end{array}$ \\
\hline $\begin{array}{l}\text { Каталаза, } \\
\text { ммоль } \mathrm{H}_{2} \mathrm{O}_{2} / \text { хв·мг білка }\end{array}$ & $18,21 \pm 0,55$ & $\begin{array}{c}12,73 \pm 0,71 \\
p_{1}<0,001\end{array}$ & $\begin{array}{c}10,09 \pm 0,28 \\
p_{1}<0,001\end{array}$ & $\begin{array}{l}7,13 \pm 0,23 \\
\mathrm{p}_{1}<0,001 \\
\mathrm{p}_{2}<0,001\end{array}$ \\
\hline
\end{tabular}

Примітки. Тут і в таблиці 2:

1. $p_{1}$ - зміни достовірні відносно показників контрольних тварин.

2. $\mathrm{p}_{2}$ - достовірність змін між тваринами 3 “пасивним тютюнокурінням” і щурами, яким моделювали “пасивне тютюнокуріння" і вводили натрій глутамат.

Цей ензим каталізує реакцію дисмутації, тобто взаємодію двох супероксидних радикалів кисню між собою, в результаті чого утворюються менш токсичний гідроген пероксид і кисень. За фрізіологічних умов гідроген пероксид, що утворився, використовується для синтезу гіпохлориту, який має антибактеріальні властивості, а надлишок $\mathrm{H}_{2} \mathrm{O}_{2}$ розкладають каталаза і глутатіонпероксидаза [16].

При порівнянні показників антиоксидантного захисту статевозрілих самок та самців контрольних підгруп встановлено більші значення СОД у самок. Так, супероксиддисмутазна активність у самок достовірно перевищувала аналогічний показник у самців: на 17,5 \% -у гемолізатах еритроцитів, на 23,1 \% - у супернатанті гомогенату легень. Каталазна активність при цьому достовірно не відрізнялася у різностатевих тварин.

$€$ дані, що супероксиддисмутазна активність у мозку і легенях була вищою в щурів-самок, але не встановлено суттєвої різниці в активності СОД у нирках або серці між щурами чоловічої та жіночої статей [17]. C. Borras та співавт. показали достовірно вищий рівень антиоксидантів (відновлений глутатіон, каталаза і СОД) у жінок відносно чоловіків [18]. Ү. Chen та співавт. пові- домили про однакову каталазну активність у мозку, серці та легенях самок і самців, але вищу каталазну активність у нирках самок [17]. Було висунуто гіпотезу, що активація рецепторів естрогену індукує надмірну експресію антиоксидантних ензимів [19]. Однак деякі дослідження не показали різниці в активності антиоксидантних ензимів між самками та самцями [20].

Проведені дослідження показали, що супероксиддисмутазна активність у гемолізатах еритроцитів статевозрілих самців за умови "пасивного тютюнокуріння" достовірно знизилась на 28,8 \% відносно контрольної групи (табл. 1), а в супернатанті гомогенату легень - на 53,1 \% (табл. 2). "Пасивне тютюнокуріння" на тлі застосування натрій глутамату супроводжувалося ще більшим її зниженням (на 41,0 \%, p<0,001) відносно контрольної групи, що на 17,1 \% (p<0,02) менше від даного показника при ізольованій дії тютюнового диму. В супернатанті гомогенату легень супероксиддисмутазна активність достовірно знизилася на 58,7 \%, що на 12,0 \% $(p<0,02)$ менше, ніж за умови ізольованої дії тютюнового диму. При цьому тривале введення натрій глутамату зумовило її зниження в гемолізаті еритроцитів на $17,7 \%(\mathrm{p}<0,001)$ порівняно з даними 
Таблиця 2 - Вплив “пасивного тютюнокуріння" і натрій глутамату на показники антиоксидантного захисту в супернатанті гомогенату легень щурів (M $\pm m, n=8)$

\begin{tabular}{|c|c|c|c|c|}
\hline \multirow[b]{2}{*}{ Показник } & \multicolumn{4}{|c|}{ Підгрупа тварин } \\
\hline & контроль & $\begin{array}{c}\text { "пасивне } \\
\text { тютюнокуріння" }\end{array}$ & натрій глутамат & $\begin{array}{c}\text { “пасивне } \\
\text { тютюнокуріння"+натрій } \\
\text { глутамат }\end{array}$ \\
\hline \multicolumn{5}{|c|}{ Статевозрілі щури-самці } \\
\hline $\begin{array}{l}\text { СОД, } \\
\text { ум. од./мг білка }\end{array}$ & $21,75 \pm 0,95$ & $\begin{array}{c}10,20 \pm 0,33 \\
p_{1}<0,001\end{array}$ & $\begin{array}{c}14,56 \pm 0,53 \\
p_{1}<0,001\end{array}$ & $\begin{array}{c}8,98 \pm 0,25 \\
p_{1}<0,001 \\
p_{2}<0,02\end{array}$ \\
\hline $\begin{array}{l}\text { Каталаза, } \\
\text { ммоль } \mathrm{H}_{2} \mathrm{O}_{2} / \text { хв·мг білка }\end{array}$ & $13,52 \pm 0,80$ & $\begin{array}{c}8,17 \pm 0,26 \\
p_{1}<0,001\end{array}$ & $\begin{array}{c}10,32 \pm 0,64 \\
p_{1}<0,001\end{array}$ & $\begin{array}{c}6,88 \pm 0,33 \\
p_{1}<0,001 \\
p_{2}<0,02\end{array}$ \\
\hline \multicolumn{5}{|c|}{ Статевозрілі щури-самки } \\
\hline $\begin{array}{l}\text { СОД, } \\
\text { ум. од./мг білка }\end{array}$ & $26,78 \pm 0,85$ & $\begin{array}{l}8,11 \pm 0,41 \\
p_{1}<0,001\end{array}$ & $\begin{array}{c}21,75 \pm 0,79 \\
p_{1}<0,01\end{array}$ & $\begin{array}{c}6,37 \pm 0,29 \\
p_{1}<0,001 \\
p_{2}<0,02\end{array}$ \\
\hline $\begin{array}{l}\text { Каталаза, } \\
\text { ммоль } \mathrm{H}_{2} \mathrm{O}_{2} / \text { хв·мг білка }\end{array}$ & $14,54 \pm 0,60$ & $\begin{array}{l}6,98 \pm 0,27 \\
p_{1}<0,001\end{array}$ & $\begin{array}{c}10,41 \pm 0,54 \\
p_{1}<0,001\end{array}$ & $\begin{array}{c}5,95 \pm 0,21 \\
p_{1}<0,001 \\
p_{2}<0,02\end{array}$ \\
\hline \multicolumn{5}{|c|}{ Статевонезрілі щури-самці } \\
\hline $\begin{array}{l}\text { СОД, } \\
\text { ум. од./мг білка }\end{array}$ & $20,46 \pm 1,13$ & $\begin{array}{l}7,11 \pm 0,25 \\
\mathrm{p}_{1}<0,001\end{array}$ & $\begin{array}{c}12,03 \pm 0,23 \\
p_{1}<0,001\end{array}$ & $\begin{array}{c}4,47 \pm 0,27 \\
p_{1}<0,001 \\
p_{2}<0,001\end{array}$ \\
\hline $\begin{array}{l}\text { Каталаза, } \\
\text { ммоль } \mathrm{H}_{2} \mathrm{O}_{2} / \text { хв·мг білка }\end{array}$ & $14,97 \pm 0,72$ & $\begin{array}{c}5,98 \pm 0,22 \\
p_{1}<0,001\end{array}$ & $\begin{array}{c}8,72 \pm 0,27 \\
p_{1}<0,001\end{array}$ & $\begin{array}{c}3,94 \pm 0,18 \\
p_{1}<0,001 \\
p_{2}<0,001\end{array}$ \\
\hline
\end{tabular}

контрольних тварин, а в супернатанті гомогенату легень - на 33,0 \% (p<0,001).

У статевозрілих самок "пасивне тютюнокуріння" супроводжувалося зниженням супероксиддисмутазної активності в гемолізатах еритроцитів на 45,9 \% (р<0,001) відносно контрольної групи, а в супернатанті гомогенату легень - на 69,7 \% (p<0,001). "Пасивне тютюнокуріння" на тлі застосування натрій глутамату супроводжувалося ще більшим її зниженням (на $56,5 \%$, р<0,001) відносно контрольної групи, що на 19,7 \% (p<0,01) менше від даного показника при ізольованій дії тютюнового диму. В супернатанті гомогенату легень супероксиддисмутазна активність достовірно знизилася на 76,2 \%, що на 21,4 \% (p<0,02) менше, ніж за умови ізольованої дії тютюнового диму. При цьому тривале введення натрій глутамату зумовило їі зниження на 8,9 \% $(p<0,05)$ порівняно 3 даними контрольних тварин, а в супернатанті гомогенату легень на $18,8 \%(p<0,01)$.

У статевому аспекті інтенсивність змін супероксиддисмутазної активності в гемолізатах еритроцитів та супернатанті гомогенату легень перевищувала показники статевозрілих самців: за умови "пасивного тютюнокуріння" - на 17,1 і 16,6 \%, при “пасивному тютюнокуріні” на тлі застосування натрій глутамату - на 15,5 та 17,5 \% відповідно.
У статевонезрілих самців "пасивне тютюнокуріння" супроводжувалося зниженням супероксиддисмутазної активності в гемолізатах еритроцитів на 50,5 \% (p<0,001) відносно контрольної групи, а в супернатанті гомогенату легень - на 68,3 \% (p<0,001). "Пасивне тютюнокуріння" на тлі застосування натрій глутамату супроводжувалося більш вираженим її зниженням (на 66,8 \%, р<0,001) відносно контрольної групи, що на 32,9 \% ( $<<0,001)$ менше від даного показника при ізольованій дії тютюнового диму. В супернатанті гомогенату легень супероксиддисмутазна активність достовірно знизилася на 80,1 \%, що на 37,1 \% ( $p<0,001)$ менше, ніж за умови ізольованої дії тютюнового диму. При цьому тривале введення натрій глутамату зумовило її зниження на 23,4\% $(p<0,001)$ порівняно з даними контрольних тварин, а в супернатанті гомогенату легень - на 46,4\% $\%(p<0,001)$.

У статевонезрілих самців інтенсивність змін супероксиддисмутазної активності в гемолізатах еритроцитів та супернатанті гомогенату легень відносно статевозрілих тварин усіх дослідних груп була вищою: за умови “пасивного тютюнокуріння" - на 21,7 і 15,2 \%, при введенні натрій глутамату - на 5,7 та 13,4 \%, за умови "пасивного тютюнокуріння" на тлі застосування натрій глутамату - на 25,8 і 21,4 \% відповідно. 
Каталазна активність у гемолізатах еритроцитів статевозрілих самців за умови "пасивного тютюнокуріння" достовірно знизилась на 16,4 \% відносно контрольної групи, а в супернатанті гомогенату легень - на 39,6 \%. “Пасивне тютюнокуріння" на тлі застосування натрій глутамату супроводжувалося ще більшим її зниженням (на 41,9 \%, p<0,001) відносно контрольної групи, що на 30,5 \% (p<0,001) менше від даного показника при ізольованій дії тютюнового диму. В супернатанті гомогенату легень каталазна активність достовірно знизилася на 49,1 \%, що на 15,8 \% $(p<0,02)$ менше, ніж за умови ізольованої дії тютюнового диму. При цьому тривале введення натрій глутамату зумовило її зниження на 33,3 \% ( $<<0,001)$ порівняно $з$ даними контрольних тварин, а в супернатанті гомогенату легень - на $23,7 \%(p<0,001)$.

У статевозрілих самок "пасивне тютюнокуріння" супроводжувалося зниженням каталазної активності в гемолізатах еритроцитів на 27,9 \% ( $<<0,002)$ відносно контрольної групи, а в супернатанті гомогенату легень - на 52,0 \%. "Пасивне тютюнокуріння" на тлі застосування натрій глутамату супроводжувалося ще більшим її зниженням (на 56,9 \%, р<0,001) відносно контрольної групи, що на 40,2 \% ( $<<0,001)$ менше від даного показника при ізольованій дії тютюнового диму. В супернатанті гомогенату легень каталазна активність достовірно знизилася на $59,1 \%$, що на $14,7 \%(p<0,02)$ менше, ніж за умови ізольованої дії тютюнового диму. При цьому тривале введення натрій глутамату зумовило зниження каталазної активності на 37,5 \% $(p<0,001)$ порівняно 3 даними контрольних тварин, а в супернатанті гомогенату легень - на $28,4 \%(p<0,001)$.

У статевому аспекті інтенсивність змін каталазної активності в гемолізатах еритроцитів та супернатанті гомогенату легень перевищувала показники статевозрілих самців: за умови "пасивного тютюнокуріння" - на 11,5 і 12,4 \%, при "пасивному тютюнокурінні" на тлі застосування натрій глутамату - на 15,0 та 10 \% відповідно. За умови введення натрій глутамату інтенсивність змін каталазної активності була вищою на 4,2 та 5,2 \% відповідно відносно змін показника статевозрілих самців.

У статевонезрілих самців "пасивне тютюнокуріння" супроводжувалося зниженням каталазної активності в гемолізатах еритроцитів на 30,1 \% (p<0,001) відносно контрольної групи, а в супернатанті гомогенату легень - на 60,0 \% ( $<<0,001)$. “Пасивне тютюнокуріння" на тлі застосування натрій глутамату супроводжувалося більш вираженим її зниженням (на 60,8 \%, p<0,001) відносно контрольної групи, що на
44,0 \% ( $<<0,001)$ менше від даного показника при ізольованій дії тютюнового диму. В супернатанті гомогенату легень каталазна активність достовірно знизилася на 73,7 \%, що на 34,1 \% $(p<0,001)$ менше, ніж за умови ізольованої дії тютюнового диму. При цьому тривале введення натрій глутамату зумовило ії зниження на 44,6 \% $(p<0,001)$ порівняно з даними контрольних тварин, а в супернатанті гомогенату легень - на $41,7 \%(p<0,001)$.

У статевонезрілих самців інтенсивність змін каталазної активності в гемолізатах еритроцитів та супернатанті гомогенату легень відносно статевозрілих тварин усіх дослідних груп була вищою: за умови "пасивного тютюнокуріння" - на 13,7 і 20,4 \%, при введенні натрій глутамату - на 11,3 та 18,0 \%, за умови "пасивного тютюнокуріння" на тлі застосування натрій глутамату - на 18,9 і 22,8 \% відповідно.

Механізми тютюніндукованого оксидативного стресу перш за все пов'язані з тим, що тютюновий дим містить речовини, які безпосередньо $€$ джерелом АФК (супероксиданіон-радикал, гідроген пероксид, гідроксильний радикал). Усього, за даними D. G. Yanbaeva та співавт., тютюновий дим містить $10^{17}$ молекул оксидантів на один вдих [21]. Крім того, індукована тютюновим димом активація запальних клітин сприяє підвищенню продукування оксидантів у тканинах.

За умов введення натрій глутамату дихальний ланцюг мітохондрій є основним джерелом АФК. Крім того, збільшення позаклітинного рівня глутамату підвищує продукування гідроксильних радикалів. Дослідження А. Sharma показали зростання активності $\alpha$-кетоглутаратдегідрогенази за умов застосування натрій глутамату, що може активувати кисень та генерацію супероксиданіон-радикала і гідроген пероксиду [22]. Однак більшість учених пов'язує виникнення оксидативного стресу з глутаматними рецепторами [23, 24]. Активація метаботропних рецепторів призводить до збільшення рівня цАМФ і вивільнення кальцію з внутрішньоклітинних депо. Змінюється рівень кальцію, і це викликає різні клітинні реакції, включаючи активацію NO-синтази, протеїнкінази C, що, у свою чергу, активує утворення АФК та ліпопероксидацію.

Таким чином, отримані дані свідчать про те, що введення натрій глутамату підсилює прооксидний ефект тютюнового диму. Очевидно, саме оксидативний стрес, який проявляється підвищенням генерації активних фрорм кисню, зумовив зниження супероксиддисмутазної і каталазної активності в нашому дослідженні. Проте значне зменшення активності СОД і каталази можна пояснити не лише використанням ензимів у процесі інактивації високореакційних 
форм кисню. Слід зазначити, що металовмісні ензими також підлягають окиснювальній модифрікації з втратою іонів металів, утворенням фррагментів пептидів і подальшим руйнуванням внутрішньоклітинними протеазами [25].

ВИСНОВКИ. 1. Надмірне утворення продуктів вільнорадикального окиснення за умови ізольованої дії тютюнового диму зумовлює виснаження антиоксидантного потенціалу крові та тканин легень, що проявляється достовірним зменшенням супероксиддисмутазної активності в гемолізатах еритроцитів на 28,8 \% відносно контрольної групи, а в супернатанті гомогенату легень - на 53,1 \% ( $<<0,001)$ відповідно. "Пасивне тютюнокуріння" на тлі застосування натрій глутамату супроводжується більшим її зниженням (на 41,0 \%, p<0,001) відносно контрольної групи, що на $17,1 \%(p<0,02)$ менше від даного показника при ізольованій дії тютюнового диму в гемолізатах еритроцитів та на 58,7 \% - у супернатанті гомогенату легень, що на 12,0 \% $(p<0,02)$ нижче від цього показника за умови ізольованої дії тютюнового диму. Однонаправлені зміни спостерігають і щодо каталазної активності.

2. У статевому аспекті показники антиоксидантного захисту за умови “пасивного тютюнокуріння" на тлі застосування натрій глутамату більш виражено знижуються в самок, а при віковому зіставленні змін активності даних ензимів встановлено їх інтенсивніше зменшення у статевонезрілих щурів.

\section{СПИСОК ЛІТЕРАТУРИ}

1. U.S. Department of Health and Human Services. Preventing Tobacco Use Among Youth and Young Adults: A Report of the Surgeon General. Atlanta, GA: U.S. Department of Health and Human Services, Centers for Disease Control and Prevention, National Center for Chronic Disease Prevention and Health Promotion, Office on Smoking and Health. - 2012.

2. Zeiher J. Smoking behaviour among children and adolescents in Germany. Results of the cross-sectional KiGGS Wave 2 study and trends / J. Zeiher, A. Starker, B. Kuntz // Journal of Health Monitoring. - 2018. - 3 (1). P. $38-44$.

3. Reitsma M.B. Smoking prevalence and attributable disease burden in 195 countries and territories, 19902015: a systematic analysis from the Global Burden of Disease Study 2015 / M. B. Reitsma, N. Fullman, M. Ng // The Lancet. - 2017. - 389 (10082). - P. 1885-1906.

4. WHO report on the global tobacco epidemic, 2017. Monitoring tobacco use and prevention policies. WHO, Geneva. Available at: http://www.who.int/fctc/mediacentre/ press-release/wntd-2017/en/.

5. Глобальне опитування дорослих щодо вживання тютюну (Global Adult Tobacco Survey - GATS) (укр. мова). - К., 2017. - 240 c.

6. Бельтюкова С. В. Определение глутамата натрия методом тонкослойной хроматограсрии с люминесцентным детектированием / С. В. Бельтюкова, Е. В. Малинка // Вісн. ОНУ. Хімія. - 2016. - 21, № 1 (57). - С. 50-58.

7. Влияние глутамата натрия на развитие микрофлоры и биохимические свойства соленой сельди / М. В. Гончаренко, Д. А. Тюрина, М. Н. Альшевская, В. И. Шендерюк // Вестн. АГТУ. Серия "Рыбное хозяйство". - 2011. - № 2. - С. 143-147.

8. Коваленко В. М. Молекулярно-генетичні особливості фрункціонування параоксонази та її значення в розвитку серцево-судинної патології / В. М. Коваленко, О. Б. Кучменко, Л. С. Мхітарян // Укр. кардіол. журн. - 2014. - 5. - С. 105-116.
9. Соломина А. С. Влияние афробазола на генетическую и репродуктивную токсичность табачного дыма у крыс : дисс. ... канд. биол. наук : 14.03.06 / Соломина Анна Сергеевна. - М., 2011. - 139 с.

10. Лизурчик Л. В. Влияние табачного дыма на содержание токсичных элементов в организме крыс / Л. В. Лизурчик, Е. В. Шейда // Вестн. ОГУ. - 2014. № 6 (167). - С. 71-74.

11. Влияние глипролинов на структурно-функциональное состояние слизистой оболочки желудка и массу тела крыс в условиях длительного введения глутамата натрия / Т. М. Фалалеева, Г. Е. Самонина, Т. В. Береговая [и др.] // Фізика живого. - 2010. - 18, № 1. - С. 154-159.

12. European convention for the protection of vertebrate animals used for experimental and other scientific purposes. - Council of Europe. Strasbourg. 1986. - No. 123. -52 p.

13. Чевари С. Роль супероксиддисмутазы в окислительных процессах клетки и метод определения ее в биологическом материале / С. Чевари, И. Чаба, Й. Секей // Лаб. дело. - 1985. - № 11. - С. 678-681.

14. Дудин В. И. Колориметрическое определение перекиси водорода при измерении активности каталазы в крови / В. И. Дудин // Проблемы биологии продуктивных животных. - 2008. - № 2. - С. 96-99.

15. Доценко О. И. Активность супероксиддисмутазы и каталазы в эритроцитах и некоторых тканях мышей в условиях низкочастотной вибрации / О. И. Доценко, В. А. Доценко, А. М. Мищенко // Физика живого. - 2010. - 18, № 1. - С. 107-113.

16. Криницька І. Я. Роль активних фрорм кисню у розвитку гепатопульмонального синдрому в експерименті / І. Я. Криницька // Здобутки клініч. і експерим. медицини. - 2012. - № 1. - С. 72-76.

17. Chen Y. Evaluation of gender-related differences in various oxidative stress enzymes in mice / Y. Chen, L. L. Ji, T. Y. Liu // Chinese J. Physiol. - 2011. - 54. P. 385-390. 
18. Mitochondria from females exhibit higher antioxidant gene expression and lower oxidative damage than males / C. Borras, J. Sastre, D. Garcia-Sal [et al.] // Free Radic Biol Med. - 2003. - 34. - P. 546-552.

19. Why females live longer than males? Importance of the upregulation of longevity-associated genes by oestrogenic compounds / J. Vina, C. Borras, J. Gambini [et al.] // FEBS Lett. - 2005. - 579. - P. 2541-2545.

20. Gomez-Perez Y. Sex-dependent effects of highfat-diet feeding on rat pancreas oxidative stress / Y. Gomez-Perez, M. Gianotti, I. Llado // Pancreas. 2011. - 40. - P. 682-628.

21. Systemic effects of smoking / D. G. Yanbaeva, M. A. Dentener, E. C. Creutzberg [et al.] // Chest. -2007. 131 (5). - P. 1557-1566.

22. Sharma A. Monosodium glutamate-induced oxidative kidney damage and possible mechanisms: a mini-review / A. Sharma // Journal of Biomedical Science. - 2015. - 22. - P. 93.

23. Siniscalco D. The expression of caspases is enhanced in peripheral blood mononuclear cells of autism spectrum disorder patient / D. Siniscalco, A. Sapone, C. Giordano // J. Autism Dev. Disord. - 2012. - 42. P. 1403-1410.

24. Kurnianingsih N. Monosodium glutamate exposure at early developmental stage increases apoptosis and stereotypic behavior risks on zebrafish (danio rerio) larvae / N. Kurnianingsih, J. P. Utami, D. Nurdiana // Indonesian J. Pharm. - 2016. - 27, No. 3. - P. 128-138.

25. Li P. F. Oxidative modification of bovine erythrocyte superoxide dismutase by hydrogen peroxide and ascorbate-Fe (III) / P. F. Li, Y. Z. Fang, X. Lu // Biochem. Mol. Biol. Int. - 1993. - 29, No. 5. - P. 929-937.

\section{REFERENCES}

1. U.S. Department of Health and Human Services (2012). Preventing Tobacco Use Among Youth and Young Adults: A Report of the Surgeon General. Atlanta, GA: U.S. Department of Health and Human Services, Centers for Disease Control and Prevention, National Center for Chronic Disease Prevention and Health Promotion, Office on Smoking and Health.

2. Zeiher, J. (2018). Smoking behaviour among children and adolescents in Germany. Results of the cross-sectional KiGGS Wave 2 study and trends. Journal of Health Monitoring, 3 (1), 38-44.

3. Reitsma, M.B. (2017). Smoking prevalence and attributable disease burden in 195 countries and territories, 1990-2015: a systematic analysis from the Global Burden of Disease Study 2015. The Lancet, 389 (10082), 1885-1906.

4. WHO report on the global tobacco epidemic (2017). Monitoring tobacco use and prevention policies. WHO, Geneva. Retrieved from: http://www.who.int/fctc/ mediacentre/press-release/wntd-2017/en/.

5. (2017). Hlobalne opytuvannia doroslykh shchodo vzhyvannia tiutiunu - GATS [Global adult tobacco survey - GATS]. Kyiv [in Ukrainian].

6. Beltyukova, S.V. \& Malinka, E.V. (2016). Opredeleniye glutamata natriya metodom tonkosloynoy khromatografii s lyuminestsentnim detektirovaniyem [Determination of sodium glutamate by thin layer chromatography with luminescent detection]. Visnyk Odeskoho natsionalnoho universytetu. Khimiia - Bulletin of Odesa National University. Chemistry, 21, 1 (57) [in Russian].

7. Goncharenko, M.V., Tyurina, D.A., Alshevskaya, M.N. \& Shenderyuk, V.I. (2011). Vliyaniye glutamata natriya na razvitiye mikroflory i biokhimicheskiye svoystva solenoy seldi [Effect of sodium glutamate on the development of microflora and the biochemical properties of salted herring]. Vestnik AGTU - Bulletin of the State Technical University, 2, 143-147 [in Russian].
8. Kovalenko, V.M. (2014). Molekuliarno-henetychni osoblyvosti funktsionuvannia paraoksonazy ta yii znachennia $v$ rozvytku sertsevo-sudynnoi patolohii [Molecular-genetic features of the functioning of paraoxonase and its importance in the development of cardiovascular pathology]. Ukrainskyi kardiolohichnyi zhurnal - Ukrainian Cardiology Journal, 5, 105-116 [in Ukrainian].

9. Solomina, A.S. (2011). Vliyanie afobazola na geneticheskuyu i reproduktivnuyu toksichnost tabachnogo dyma u krys [The effect of afobazole on the genetic and reproductive toxicity of tobacco smoke in rats]. Candidate's thesis. Moscow: V.V. Zakusov Research Institute of Pharmacology of the RAMS [in Russian].

10. Lizurchik, L.V. \& Sheyda, E.V. (2014). Vliyanie tabachnogo dyma na soderzhaniye toksichnykh elementov $v$ organizme krys [Effect of tobacco smoke on the content of toxic elements in the body of rats]. Vestnik OGU - Journal of the Orenburg State University, 6 (167), 71-74 [in Russian].

11. Falaleyeva, T.M., Samonina, G.E., Beregovaya, T.V., Dzyubenko, N.V. \& Andreyeva, L.A. (2010). Vliyanie gliprolinov na strukturno-funktsionalnoye sostoyanie slizistoy obolochki zheludka i massy tela krys $v$ usloviyakh dlitelnogo vvedeniya glutamata natriya [The effect of glyprolines on the structural and functional state of the gastric mucosa and the body weight of rats under conditions of prolonged administration of sodium glutamate]. Fizyka zhyvoho - Journal of the Physics of the Living, 18 (1), 154-159 [in Russian].

12. Council of Europe (1986). European convention for the protection of vertebrate animals used for experimental and other scientific purposes. Strasbourg.

13. Chevari, S. (1985). Rol superoksiddismutazy v okislitelnykh protsessakh kletki i metod opredeleniya ee $v$ biologicheskom materiale [The role of superoxide dismutase in the oxidative processes of the cell and the method of its determination in biological material]. 
Lab. delo. - Laboratory Business, 11, 678-681 [in Russian].

14. Dudin, V.I. (2008). Kolorimetricheskoye opredeleniye perekisi vodoroda pri izmerenii aktivnosti katalazy v krovi [Colorimetric determination of hydrogen peroxide in the measurement of catalase activity in the blood]. Problemy biologii produktivnykh zhivotnykh - The Problems of the Biology of Productive Animals, 2, 96-99 [in Russian].

15. Dotsenko, O.I. (2010). Aktivnost superoksiddismutazy i katalazy v eritrotsitakh i nekotorykh tkanyakh myshey $v$ usloviyakh nizkochastotnoy vibratsii [The activity of superoxide dismutase and catalase in erythrocytes and some tissues of mice under conditions of low-frequency vibration]. Fizika zhivogo - Physics of the Living, 18, (1), 107-113 [in Russian].

16. Krynytska, I.Ya. (2012). Rol aktyvnykh form kysniu u rozvytku hepatopulmonalnoho syndromu v eksperymenti [The role of active forms of oxygen in the development of hepatopulmonary syndrome in the experiment]. Zdobutky klinichnoi i eksperymentalnoi medytsyny - Achievements of Clinical and Experimental Medicine, 1, 72-76 [in Ukrainian].

17. Chen, Y. (2011). Evaluation of gender-related differences in various oxidative stress enzymes in mice. Chinese J. Physiol., 54, 385-390.

18. Borras, C. (2003). Mitochondria from females exhibit higher antioxidant gene expression and lower oxidative damage than males. Free Radic. Biol. Med., 34, 546-552.

19. Vina, J. (2005). Why females live longer than males? Importance of the upregulation of longevity-associated genes by oestrogenic compounds. FEBS Lett, 579, 2541-2545.

20. Gomez-Perez, Y. (2011). Sex-dependent effects of high-fat-diet feeding on rat pancreas oxidative stress. Pancreas, 40, 682-628.

21. Yanbaeva, D.G. (2007). Systemic effects of smoking. Chest, 131(5), 1557-1566.

22. Sharma, A. (2015). Monosodium glutamateinduced oxidative kidney damage and possible mechanisms: a mini-review. Journal of Biomedical Science, 22, 93.

23. Siniscalco, D. (2012). The expression of caspases is enhanced in peripheral blood mononuclear cells of autism spectrum disorder patient. J. Autism Dev. Disord., 42, 1403-1410.

24. Kurnianingsih, N. (2016). Monosodium glutamate exposure at early developmental stage increases apoptosis and stereotypic behavior risks on zebrafish (danio rerio) larvae. Indonesian J. Pharm, 27 (3), 128-138.

25. Li, P.F. (1993). Oxidative modification of bovine erythrocyte superoxide dismutase by hydrogen peroxide and ascorbate-Fe (III). Biochem. Mol. Biol. Int., 29, 5, 929-937.

\section{ИССЛЕДОВАНИЕ ЭНЗИМНОГО ЗВЕНА АНТИОКСИДАНТНОЙ СИСТЕМЫ У КРЫС ПРИ ВОЗДЕЙСТВИИ ТАБАЧНОГО ДЫМА НА ФОНЕ ПРИМЕНЕНИЯ НАТРИЙ ГЛУТАМАТА В ПОЛОВОМ И ВОЗРАСТНОМ АСПЕКТАХ}

\section{Резюме}

Вступление. Значительная распространенность табакокурения - глобальная проблема человечества, на решение которой направлены усилия многих ученых и специалистов. В то же время отличительной особенностью современных пищевых технологий является использование пищевых добавок. $K$ наиболее распространенным пищевым добавкам как в Украине, так и в Европе принадлежит натрий глутамат (E621), который не всегда безопасен для здоровья человека.

Цель исследования - изучить состояние энзимного звена антиоксидантной системы у крыс при воздействии табачного дыма на фроне применения натрий глутамата в половом и возрастном аспектах.

Методы исследования. Опыты проведены на 96 белых нелинейных половозрелых и неполовозрелых крысах обоего пола. Каждая группа животных была разделена на 4 подгруппы: 1-я - контроль; 2-я - крысы, которым моделировали "пассивное табакокурение"; 3-я - крысы, которым вводили натрий глутамат; 4-я - крысы, которым моделировали “пассивное табакокурение" на фоне введения натрий глутамата.

Результаты и обсуждение. Избыточное образование продуктов свободнорадикального окисления при изолированном воздействии табачного дыма вызывало истощение антиоксидантного потенциала крови и тканей легких, что проявлялось достоверным уменьшением супероксиддисмутазной активности в гемолизатах эритроцитов на 28,8 \% относительно контрольной группы, а в супернатанте гомогената легких - на 53,1 \% (р<0,001) соответственно. "Пассивное табакокурение" на фроне применения натрий глутамата сопровождалось большим ее снижением (на 41,0\%, p<0,001) относительно контрольной группы, что на 17,1% (p<0,02) ниже данного показателя при изолированном воздействии табачного дыма в гемолизатах эритроцитов и на 58,7 \% - в супернатанте гомогената легких, на 12,0 \% $(p<0,02)$ ниже этого показателя в условиях изолированного воздействия табачного дыма. Однонаправленные изменения наблюдали и в отношении каталазной активности. 
Выводы. При воздействии табачного дыма наблюдают истощение антиоксидантного потенциала (снижение супероксиддисмутазной и каталазной активности) крови и ткани легких, более выраженное при "пассивном табакокурении" на фроне применения натрий глутамата. В половом аспекте показатели антиоксидантной защиты в условиях "пассивного табакокурения" на фроне применения натрий глутамата более выражено снижаются у самок, а при возрастном сопоставлении изменений активности данных фрерментов установлено их более интенсивное уменьшение у неполовозрелых крыс.

КЛЮЧЕВЫЕ СЛОВА: табачный дым; натрий глутамат; антиоксидантная система.

A. V. Rutska

I. HORBACHEVSKY TERNOPIL STATE MEDICAL UNIVERSITY

\section{STUDY OF AN ENZYME ANTIOXIDANT PROTECTION IN RATS IN CASE OF TOBACCO SMOKE COMBINED WITH PROLONGED ADMINISTRATION OF MONOSODIUM GLUTAMATE IN THE SEX AND AGE ASPECTS}

Introduction. The widespread prevalence of tobacco smoking is a global problem of humanity, the solution of which is directed at the efforts of many scientists and professionals. At the same time, the distinctive feature of modern food technologies is the use of nutritional supplements. One of the most common nutritional supplements in Ukraine and in Europe is glutamate sodium (E621), which is not always safe for human health.

The aim of the study - to investigate the state of the enzyme level of the antioxidant system in rats during "passive tobacco smoking" on the basis of prolonged administration of monosodium glutamate in the sex and age aspects.

Research Methods. The study was conducted on 96 white, non-linear, sexually mature and sexually immature rats of both sexes. Each group of animals was divided into four subgroups: I - control; II - rats, which were modeled "passive tobacco smoking"; III - rats, which were given monosodium glutamate; IV - rats, which were modeled "passive tobacco smoking" against the background of the introduction of monosodium glutamate.

Results and Discussion. Excessive formation of products of free radical oxidation under the condition of isolated effect of tobacco smoke causes the extinction of the antioxidant potential of blood and lung tissues, which is manifested by a significant decrease in superoxide dismutase activity in erythrocytes hemolysates by $28.8 \%$ vs the control group, and in the supernatant of the lung homogenate - by $53.1 \%(p<0.001)$ respectively. "Passive tobacco smoking" against the background of monosodium glutamate application is accompanied by a significant decrease in superoxide dismutase activity (by $41.0 \%(p<0.001)$ ) relative to the control group, which is by $17.1 \%$ $(p<0.02)$ below this index in case of the isolated effect of tobacco smoke in erythrocytes hemolysates and $58.7 \%$ in the supernatant of lung homogenate, which is $12.0 \%(p<0.02)$ below this index, provided that the tobacco smoke is isolated. Unidirectional changes were observed with catalase activity.

Conclusions. In case of exposure to tobacco smoke, extinction of the antioxidant potential (reduction of superoxide dismutase and catalase activity) in the blood and lung tissue is observed, which is more pronounced in the case of "passive tobacco smoking" combined with monosodium glutamate application. In the sexual aspect, the indices of antioxidant protection in the context of "passive tobacco smoking" against the use of monosodium glutamate are more pronounced in females, and with the age-old comparison of changes in the activity of these enzymes established their more intense decline in immature rats.

KEY WORDS: tobacco smoke; monosodium glutamate; antioxidant system.

Отримано 07.08.18

Адреса для листування: А. В. Руцька, Тернопільський державний медичний університет імені І. Я. Горбачевського, майдан Волі, 1, Тернопіль, 46001, Україна, e-mail: nastya@tdmu.edu.ua. 